\title{
Weevil Zabrotes subfasciatus (Boheman, 1883) (Chrysomelidae: Bruchinae) Rearing in Dry Bean (Phaseolus vulgaris L.)
}

\author{
Eliane Dias Quintela ${ }^{ \pm+}$, Edmar Cardoso de Mourat, José Francisco Arruda e Silva ${ }^{\circledR}$
}

\author{
Embrapa Arroz e Feijão, Caixa Postal 179, CEP 75.375-000. Santo Antônio de Goiás, GO, Brazil. tIn memorian. \\ 表=CCorresponding author: eliane.quintela@embrapa.br
}

Edited by: Leandro D. Geremias

Received: August 21, 2019. Accepted: January 13, 2020. Published: May 30, 2020.

\begin{abstract}
Zabrotes subfasciatus (Boheman, 1833) is a cosmopolitan pest, occurring in all countries that grow dry bean, Phaseolus vulgaris L. To assure the development of quality bioassays with this insect, a rearing procedure was implemented according to Standards of Good Laboratory Practices. An average of 2,751.94 adults was produced from 300 couples, in a kilogram of dry bean, in approximately one month. The rearing methodology described herein has been conducted successfully for several generations, providing insects of quality, which have been used routinely for academic and research purposes.
\end{abstract}

Keywords: Methodological procedure, good laboratory practices, stored beans.

Zabrotes subfasciatus (Boheman, 1833) is a cosmopolitan insect, present in all countries that grow dry beans Phaseolus vulgaris L (Fig. $1 \mathrm{~A})$. It is the most important pest of stored beans, especially in the tropics, with losses estimated at 13\% (Soares et al. 2014; Guzzo et al. 2018) (Fig. 1 B). It has a fast development and a high reproductive potential, producing many generations in a short period, an excellent characteristic to be used in bioassays and classroom practices. Several research works have been performed with $Z$. subfasciatus, covering biological aspects, plant resistance, chemical insecticides, botanical extracts, and vegetable oil tests, besides studies on biological and evolutionary theories (Pereira et al. 1995; Sari et al. 2003; Marteleto et al. 2009; Paul et al. 2009; Silva et al. 2013; Guzzo et al. 2018).

Aiming to improve the quality of bioassays with this insect, the Z. subfasciatus rearing methodological procedure was implemented according to Standards Good Laboratory Practices (GLP) in the laboratory of entomology at Brazilian Agricultural Research Corporation (Embrapa Rice and Beans), in Santo Antônio de Goiás. GO. The GLP encompasses laboratory organization and the conditions under which studies are designed, performed, monitored, recorded, and reported.

Rearing starts by collecting adults of $Z$. subfasciatus of natural infestation in beans seeds at grain storage facilities. Collecting procedures should take place once a week for three weeks. The infested beans from each collection are sieved in a $2 \mathrm{~mm}$ mesh sieve and the adults, that passed through it are collected in a plastic basin, transferred to a single capacity transparent plastic bag, and taken to the laboratory.

With the help of a manual aspirator, 300 couples of Z. subfasciatus are transferred to 4-liter transparent glass bottle containing one kilogram of beans Cv. Jalo Precoce free of agrochemical residues or any other chemical. Both, female and male are brown, but the female differs from the male because it is larger and has four cream-colored spots on the wings. The flask should be capped with a fine mesh voile, tightened by the holed cap, and transferred to the rearing room. The living adults not used must be killed by placing them in a freezer for 24 hours then discarded in an organic waste container. On the label write the flask identification number (ex: 001/2011 followed by a threedigit sequential number/year); the generation number (Generation 0 ), and the name of the person in charge for the insects infestation
(Annex A). The person responsible must record that information in the record-book "weevil (Zabrotes subfasciatus) multiplication in common beans" (Annex B), an add information about the collecting places with the names of the responsible (s) for the collection. After the larvae penetrate the seeds, the flasks must be gently agitated weekly with horizontally rotating movements to avoid fungi growth, which can affect larvae development.

After 10 to 15 days, sieve the infested beans discarding the dead adults and faeces that passed through the $2 \mathrm{~mm}$ mesh sieve in an organic waste container. Beans retained in the sieve are transferred to a clean flask. The identification number; the collecting/infestation date; the generation number (Generation 0); the name of the person in charge of the infestation; the date the flask was cleaned and the name of the person in charge of the cleaning (Annex A) are recorded on the label attached to the flask. Also, transfer that information to the recordbook (Annex B) in the field designated to that flask. After 20 days the flask must be checked daily until the emergence of the first insects. The date of the beginning of the emergence must be recorded in the tag attached to the flask, as well as the name of the person responsible for the observation. That information is also recorded in the record-book (Annex B), in the field designated to that flask.

For the maintenance of the rearing, one to three days after adult emergence, it is necessary to sieve the beans and to collect the adults, faeces and bean teguments that passed through the mesh in a plastic basin. Fan the insects to remove faeces and teguments and infest the beans with the weevils, repeating all steps previously described. Next, record on the flask identification label and in the record-book the flask identification number (Ex: 002/2011); the infestation date; the number of generation (Generation 1); the number of identification of the original flask (Ex. 001/2011), and the name of the person in charge of the infestation. After six months, mix the insects collected in the three different locations in a flask (100 couples from each place/flask), totaling 300 couples per flask, to avoid endogamy. Start a new rearing each year, and discard the insects from the previous one.

The rearing room must be kept in absence of light, and relative humidity and temperature recorded daily by a Data Logger or a Thermo hygrograph. Data must be printed and pasted in the record book "control of ambient conditions of the weevil rearing room". The name 
of the person in charge of recording and the new date of data collecting must be placed near the apparatus measuring the temperature and the relative humidity. The rearing room temperature must be kept between $15^{\circ} \mathrm{C}$ and $30^{\circ} \mathrm{C}$, and relative humidity below $70 \%$. Each year the measuring apparatus must be calibrated by any laboratory of the Brazilian Calibrating Network, licensed by INMETRO with the corresponding certificate issuance.

The shelves of the rearing room must be sanitized each week using a cloth moistened with alcohol $70 \%$ and the cleaning date, next to the cleaning date, and the name of the person in charger must be recorded on the tag affixed in the room.

That rearing procedure, starting with 300 weevil couples, allows producing an average of 2,751.94 adults of $Z$. subfasciatus in one kilogram of dry beans Cv. Jalo Precoce in one month approximately (Tab. 1). The rearing methodology described in this work is being performed successfully by several generations, providing good quality insects of known age routinely used in academic and research works.
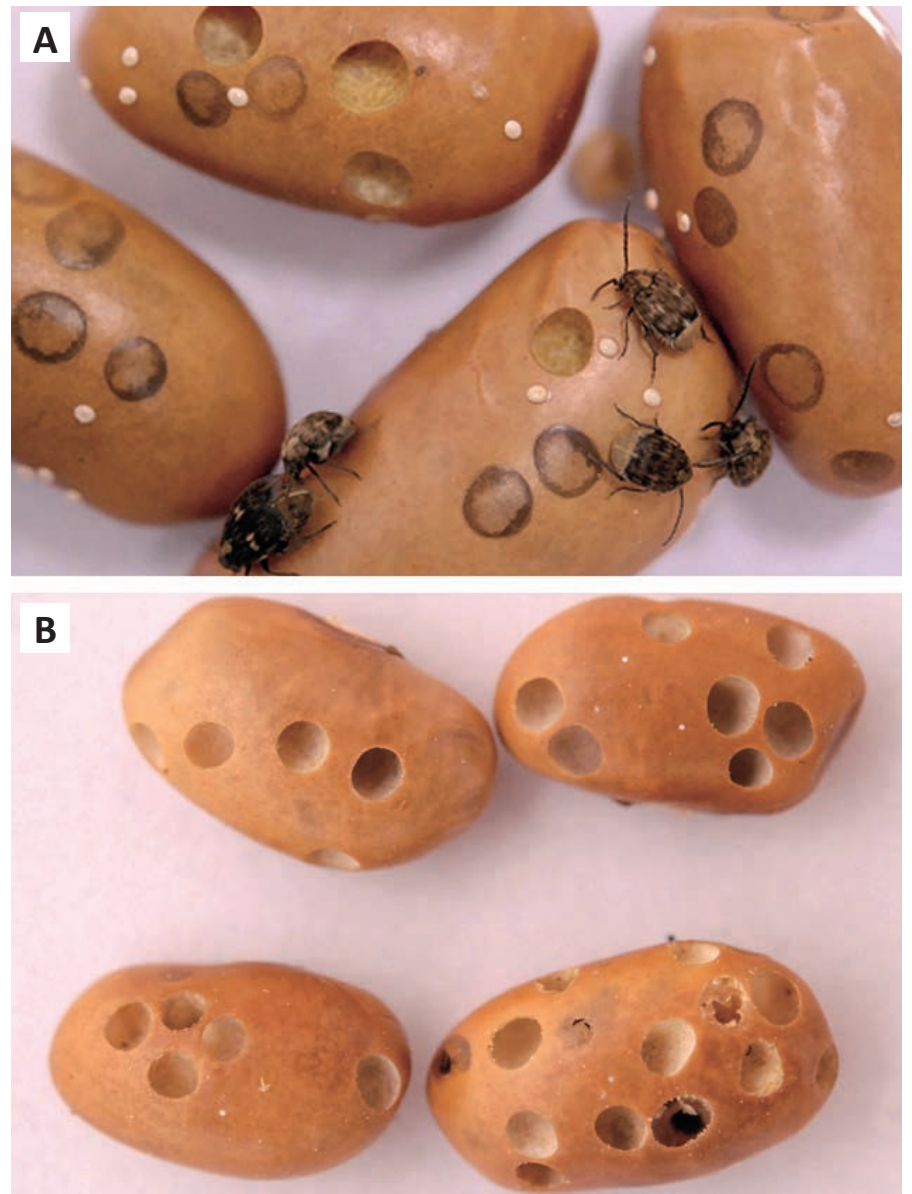

Figure 1. Bean weevil Zabrotes subfasciatus. A) Adults and eggs; B) Damage to bean seeds.

Table 1. Mean weight and number of Zabrotes subfasciatus adults reared in seeds of dry bean Cv. Jalo Precoce ${ }^{1}$.

\begin{tabular}{ccccc}
\hline $\begin{array}{c}\text { Mean weight } \\
\text { of } \mathbf{3 0 0} \text { females } \\
\pm \mathrm{SD}^{2} \mathbf{( g )}\end{array}$ & $\begin{array}{c}\text { Mean weight } \\
\text { of } \mathbf{3 0 0} \text { males } \\
\pm \mathrm{SD}^{2}(\mathbf{g})\end{array}$ & $\begin{array}{c}\text { Mean weight } \\
\text { of } \mathbf{1 , 0 0 0} \text { adults } \\
\pm \mathrm{SD}^{2}(\mathbf{g})\end{array}$ & $\begin{array}{c}\text { Mean weight } \\
\text { of total adults } \\
\pm \mathrm{SD}^{2}(\mathbf{g})\end{array}$ & $\begin{array}{c}\text { Mean number } \\
\text { of adults } \pm \mathrm{SD}^{2}\end{array}$ \\
\hline $0.9344 \pm 0.012$ & $0.5411 \pm 0.019$ & $1.9586 \pm 0.029$ & $5.3935 \pm 0.4744$ & $2,751.94 \pm 211.2$ \\
\hline
\end{tabular}

${ }^{1}$ One kilogram of beans was infested with 300 couples of Zabrotes in five replications. ${ }^{2}$ Mean Standard Deviation

\section{Acknowledgments}

We are very grateful to Ana Lúcia Delalibera de Faria for assistance with the revision of the references. This work was supported in part by Empresa Brasileira de Pesquisa Agropecuária (Embrapa/Brasília/Brazil).

\section{References}

Guzzo, E. C.; Vendramim, J. D; Lourenção, A. L.; Chiorato, A. F.; Carbonell, S. A. M.; Corrêa, O. M. B. (2018) Adult attractiveness and oviposition preference of Zabrotes subfasciatus toward genotypes of common bean Phaseolus vulgaris. Phytoparasitica, 46: 645-651. doi: 10.1007/s12600-018-0700-8

Marteleto, P. B.; Lomônaco, C.; Kerr, W. E. (2009) Respostas fisiológicas, morfológicas e comportamentais de Zabrotes subfasciatus (Boheman) (Coleoptera: Bruchidae) associadas ao consumo de diferentes variedades de feijão (Phaseolus vulgaris). Neotropical Entomology, 38:178-185. doi: 10.1590/S1519$566 \times 2009000200003$

Paul, U. V.; Lossini, J. S.; Edwards, P. J.; Hilbeck, A. (2009) Effectiveness of products from four locally grown plants for the management of Acanthoscelides obtectus (Say) and Zabrotes subfasciatus (Boheman) (both Coleoptera: Bruchidae) in stored beans under laboratory and farm conditions in Northern Tanzania. Journal of Stored Products Research, 45: 97-107. doi: 10.1016/j. jspr.2008.09.006

Pereira, P. A. A.; Yokoyama, M.; Quintela, E. D.; Bliss, F. A. (1995) Controle do caruncho Zabrotes subfasciatus (Boheman, 1833) (Coleoptera: Bruchidae) pelo uso de proteína da semente em linhagens quaseisogênicas do feijoeiro. Pesquisa Agropecuária Brasileira, 30: 10311034.

Sari, L. T.; Ribeiro-Costa, C. S.; Pereira, P. R. V. S. (2003) Aspectos biológicos de Zabrotes subfasciatus (Boheman, 1833) (Coleoptera: Bruchidae) em Phaseolus vulgaris L., cv. Carioca (Fabaceae), sob condições de laboratório. Revista Brasileira de Entomologia, 47: 621-624. doi: 10.1590/S0085-56262003000400014

Silva, J. F.; Melo, B. A.; Leite, D. T.; Almeida, F. A. C.; Pessoa, E. B. (2013) Dados biológicos de Zabrotes subfasciatus (Bohemann, 1833) (Coleoptera: Bruchidae) em dois genótipos de Phaseolus vulgaris L. Revista Verde de Agroecologia e Desenvolvimento Sustentável, 8: 6-9.

Soares, M. A.; Quintela, E. D.; Mascarin, G. M.; Arthurs, S. P. (2014) Effect of temperature on the development and feeding behavior of Acanthoscelides obtectus (Chrysomelidae: Bruchinae) on dry bean (Phaseolus vulgaris L.). Journal of Stored Products Research, 66: 1-7. doi: 10.1016/j.jspr.2014.12.005 


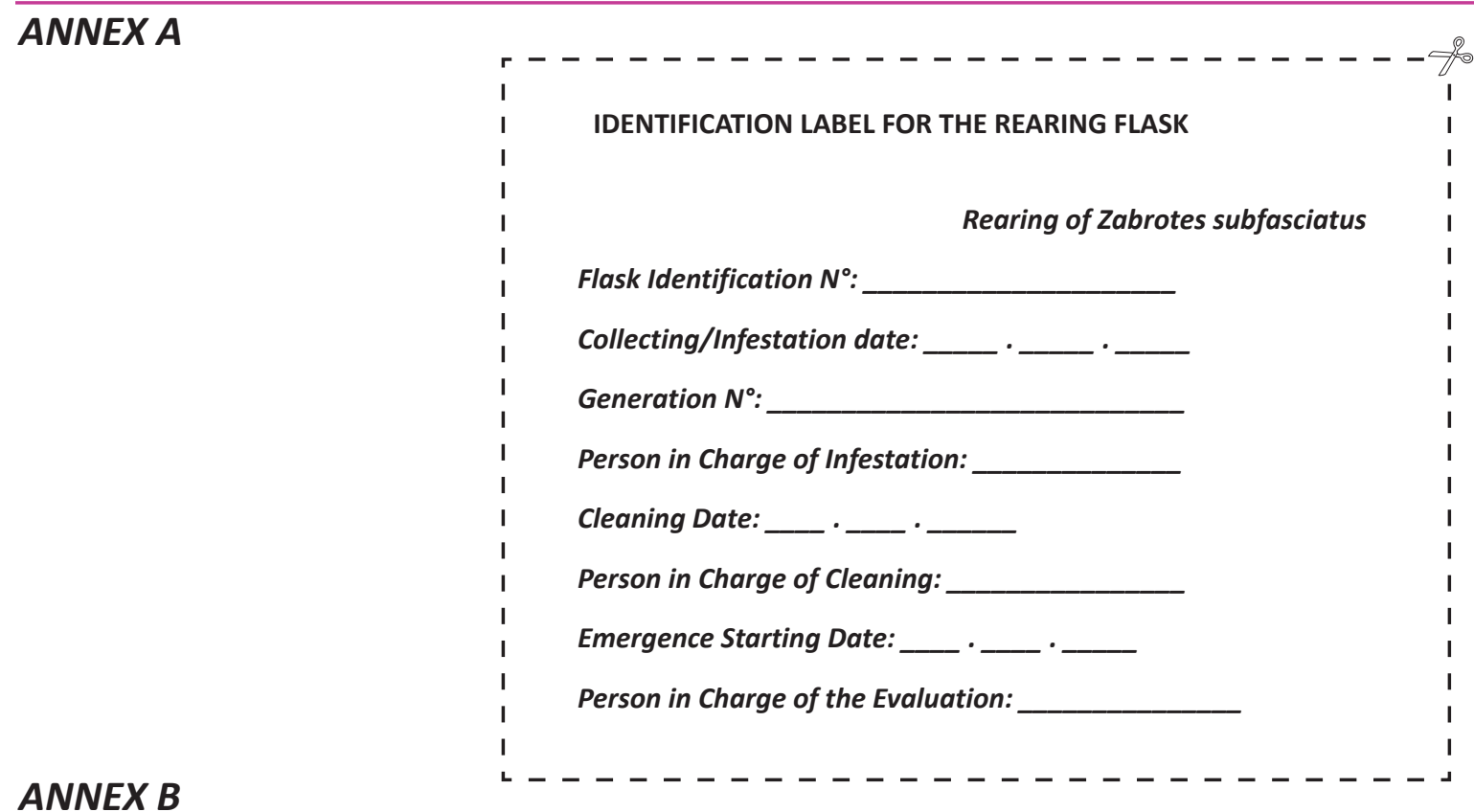

\section{ANNEX B}

FORM FOR WEEVIL, Zabrotes subfasciatus, MULTIPLICATION IN COMMON BEANS

Flask Identification $\mathrm{N}^{\circ}$ :

Collecting date/Infestation:

Generation:

Identification $\mathrm{N}^{\circ}$ on the Original flask:

Collecting places:

Person (s) in charge of the Collection:

Person in Charge of the Infestation:

Cleaning Date:

Person in Charge of the Cleaning:

Emergence Starting Date:

Person In Charge for the Evaluation:

Observations: 